\title{
Nutritional levels of digestible threonine in brown-egg laying hens from 75 to 90 weeks of age
}

\author{
Níveis nutricionais de treonina digestível para poedeiras \\ semipesadas de 75 a 90 semanas de idade
}

\author{
Márcia Antonia Bartolomeu Agustini ${ }^{1 *}$; Ricardo Vianna Nunes ${ }^{2}$; \\ Christiane Garcia Vilela²; Sabrina Endo Takahashi ${ }^{3}$; Valter Oshiro Vilela ${ }^{4}$; \\ Rachel Santos Bueno5; Clauber Polese ${ }^{6}$
}

\begin{abstract}
An experiment was conducted in the Department of Experimental Stations of the Universidade Tecnológica Federal do Parana - UTFPR campus Dois Vizinhos - PR, with the objective of determining the nutritional levels of threonine for laying hens aged 75 to 90 weeks. One hundred fifty laying Shaver Brown pullets were used in a completely randomized design (CRD) submitted to a basal diet containing $2.85 \mathrm{kcal} \mathrm{ME} / \mathrm{g}$ and $148.7 \mathrm{~g} / \mathrm{kg} \mathrm{CP}$, supplemented with $4.6 ; 4.9 ; 5.2 ; 5.5$ or $5.8 \mathrm{~g} / \mathrm{kg}$ of digestible Lthreonine $(98 \%$ ), which provided $0.000,0.027,0.058,0.089$ or $0.120 \%$ threonine, respectively. The feed conversion, egg production, egg weight, egg mass and internal egg quality were not affected $(\mathrm{P}>$ 0.05 ) by the threonine in the diet. The Haugh unit showed a linear effect with threonine consumption in that it increased levels of digestible amino acids in the diet. The variables percent albumin and shell showed quadratic effects, so the recommended dietary digestible threonine level was $5.20 \mathrm{~g} / \mathrm{kg}$, which corresponds to $0.648 \mathrm{~g}$ threonine/hen/day, and $5.25 \mathrm{~g} / \mathrm{kg}$, which is equivalent to $0.654 \mathrm{~g}$ threonine $/ \mathrm{hen} /$ day, respectively. The specific gravity was affected by the level of threonine; the indicated level is 5.22 $\mathrm{g} / \mathrm{kg}$, equivalent to $0.651 \mathrm{~g}$ of threonine/hen/day obtained by the quadratic effect.
\end{abstract}

Key words: Digestible amino acid, egg quality, performance

\section{Resumo}

Conduziu-se um experimento no Núcleo de Unidades de Ensino e Pesquisa da Universidade Tecnológica Federal do Paraná - UTFPR, Campus de Dois Vizinhos - PR, com o objetivo de determinar os níveis nutricionais de treonina digestível para poedeiras comerciais, no período de 75 a 90 semanas de idade. Foram utilizadas 150 poedeiras Shaver Brown semipesadas num delineamento inteiramente casualizado (DIC), submetidas à uma ração basal contendo $2,85 \mathrm{Kcal} \mathrm{EM} / \mathrm{g}, 148,7 \mathrm{~g} / \mathrm{kg}$ de $\mathrm{PB}$, suplementada com 4,$6 ; 4,9 ; 5,2 ; 5,5$ e $5,8 \mathrm{~g} / \mathrm{kg}$ de L-treonina digestível (98\%), que forneceu 0,000; 0,027; 0,058; 0,089 e $0,120 \%$ de treonina digestível, respectivamente. A conversão alimentar, a produção de ovos, o peso do ovo, massa de ovos e a qualidade interna dos ovos não foram influenciados $(\mathrm{P}>0,05)$ pelos níveis de treonina na dieta. A unidade Haugh e o consumo de treonina apresentaram efeito linear à medida em

${ }^{1}$ Prof ${ }^{a}$ M.e, Universidade Tecnológica Federal do Paraná, UTFPR, Medianeira, PR, Brasil. E-mail: marciaagustini@utfpr.edu.br

2 Profs. Drs., Universidade Estadual do Oeste do Paraná, UNIOESTE, Marechal Cândido Rondon, PR, Brasil. E-mail: nunesrv@ hotmail.com; chrisg_vilela@hotmail.com

3 Prof ${ }^{\mathrm{a}} \mathrm{Dr}^{\mathrm{a}}$, UTFPR, Dois Vizinhos, PR, Brasil. E-mail: sabrina@utfpr.edu.br

${ }^{4}$ Prof. M.e, UNIOESTE, Marechal Cândido Rondon, PR, Brasil. E-mail: valter@utfpr.edu.br.

5 Prof ${ }^{a}$ Dr $^{a}$, Universidade Estadual de São Paulo, USP, Pirassununga, SP, Brasil. E-mail: rbueno@usp.br

${ }^{6}$ M.e em Zootecnia da UNIOESTE, Marechal Cândido Rondon, PR, Brasil. E-mail: polesepr@yahoo.com.br

* Author for correspondence 
que aumentavam os níveis do aminoácido digestível na dieta. As variáveis porcentagem de albúmen e casca apresentaram efeito quadrático e os níveis nutricionais de treonina digestível recomendados foram de $5,20 \mathrm{~g} / \mathrm{kg}$, o que corresponde a $0,648 \mathrm{~g}$ de treonina $/$ ave $/$ dia e, $5,25 \mathrm{~g} / \mathrm{kg}$ que equivale a 0,654 $\mathrm{g}$ de treonina/ave/dia, respectivamente. A gravidade específica foi afetada pelos níveis de treonina digestível, e o nível indicado é de $5,22 \mathrm{~g} / \mathrm{kg}$, que equivale a $0,651 \mathrm{~g}$ de treonina/ave/dia obtido por meio de efeito quadrático.

Palavras-chave: Aminoácido digestível, desempenho, qualidade do ovo

\section{Introduction}

For many years, diet formulations were based entirely on their crude protein content, which resulted in diets with amino acid levels above the actual requirements of the poultry. This excess of amino acids caused a drawback overload of the liver and kidney because they lose amine radicals, leading to the formation of uric acid and increasing the level of that compound in the blood of hens. As mentioned by Aletor, Hamid and Niess (2000), this necessitates greater energy expenditure by the poultry, which are diverted from egg production to the process of nitrogen excretion.

It has been observed that laying commences earlier and which have a high peak production (CUPERTINO et al., 2009), so the challenge is to master the genetic dynamism that has created ever more demanding poultry, especially from the nutritional aspect Medina (2003).

As essential components of eggs, amino acids constitute the protein molecules present in the albumin and yolk (Leeson; Summers, 2001). Therefore, by providing an adequate supply of dietary protein and amino acids to laying hens, their development and maintenance can be ensured and nitrogen excretion minimized, in order to improve their efficient use and reduce production costs.

L-threonine is $98 \%$ digestible and is commercially available, offering great flexibility in the formulation of diets. Supplementation allows the inclusion of minor proteins and amino acids in animal diets (UMIGI et al., 2007). However, according to Faria et al. (2001), the results available in the literature are inconsistent.
Schmidt et al. (2010) conducted an experiment with laying hens 79-95 weeks of age, testing five levels of threonine (3.80 to $5.12 \mathrm{~g} / \mathrm{kg}$ ). At the end of the experiment, they recommended $4.69 \mathrm{~g} / \mathrm{kg}$ of digestible threonine. This value is very close to that recommended by Rostagno et al. (2000), requiring $4.55 \mathrm{~g} / \mathrm{kg}$ threonine for laying hens.

Considering that for layers of the second production cycle recommendations threonine are sparse, the purpose of this study was to determine the dietary digestible threonine levels for laying hens of the Shaver Brown lineage in production, in the period 75-90 weeks old.

\section{Material and Methods}

The experiment was conducted unity of teaching and research Small Animal, Universidade Tecnológica Federal do Paraná - UTFPR Campus Dois Vizinhos-PR from November 2009 to February 2010 .

One hundred fifty laying hens of the Shaver Brown lineage, 75 weeks of age, were used after the forced-molting period in which selection of the same was performed according to live weight and production. Five levels of digestible threonine were used, as five treatments and six replicates of five hens each, distributed in a completely randomized design. The diets were fed daily, three times a day, in trough type feeders, with water being supplied in troughs of the nipple type.

To determine the nutritional levels of threonine, isonutrient and isocaloric diets were formulated except for the level of supplemental L-threonine, which were presented in five different doses. Levels 
were determined based on a basal diet deficient nutrients contained in the feed (Table 1) met the in threonine, supplemented with 4.6, 4.9, 5.2, recommendations by Rostagno, Albino and Paez 5.5 or $5.8 \mathrm{~g} / \mathrm{kg}$ of digestible threonine. The other (2005).

Table 1. Ingredients and nutrient composition of the test diet.

\begin{tabular}{|c|c|c|c|c|c|}
\hline & \multicolumn{5}{|c|}{ Levels of digestible threonine $(\mathrm{g} / \mathrm{kg})$} \\
\hline & 4.60 & 4.90 & 5.20 & 5.50 & 5.80 \\
\hline Corn grain & 660.86 & 658.28 & 659.33 & 660.45 & 661.41 \\
\hline Soybean meal (45\%) & 193.65 & 196.00 & 195.41 & 194.80 & 194.20 \\
\hline Soybean oil & 19.91 & 19.91 & 19.06 & 18.33 & 17.59 \\
\hline Dicalcium phosphate & 21.23 & 21.23 & 21.21 & 21.10 & 21.20 \\
\hline Calcitic limestone & 94.11 & 94.11 & 94.11 & 94.11 & 94.07 \\
\hline Livestock salt & 3.50 & 3.50 & 3.50 & 3.50 & 3.50 \\
\hline L-Threonine (98\%) & 0.00 & 0.27 & 0.58 & 0.89 & 1.20 \\
\hline DL-Methionine (98\%) & 2.72 & 2.72 & 2.73 & 2.73 & 2.73 \\
\hline L-Lysine HCL (78\%) & 1.55 & 1.56 & 1.57 & 1,58 & 1.59 \\
\hline L-Tryptophan (98\%) & 0.30 & 0.22 & 0.30 & 0.31 & 0.31 \\
\hline Mineral supplement/Vitamins & 2.00 & 2.00 & 2.00 & 2.00 & 2.00 \\
\hline Antioxidant & 0.20 & 0.20 & 0.20 & 0.20 & 0.20 \\
\hline Total & 1000.00 & 1000.00 & 1000.00 & 1000.00 & 1000.00 \\
\hline \multicolumn{6}{|l|}{ NUTRITIONAL VALUE } \\
\hline Metabolizable energy (kcal/g) & 2.85 & 2.85 & 2.85 & 2.85 & 2.85 \\
\hline Crude Protein & 147.7 & 148.8 & 149.0 & 149.1 & 149.2 \\
\hline Calcium & 4.20 & 4.20 & 4.20 & 4.19 & 4.19 \\
\hline Phosphorus & 4.8 & 4.8 & 4.8 & 4.7 & 4.8 \\
\hline Sodium & 1.5 & 1.5 & 1.5 & 1.5 & 1.5 \\
\hline Lysine & 7.5 & 7.5 & 7.5 & 7.5 & 7.5 \\
\hline Met + Cys & 6.8 & 6.8 & 6.8 & 6.8 & 6.8 \\
\hline Digestible threonine & 4.6 & 4.8 & 5.2 & 5.5 & 5.8 \\
\hline Digestible tryptophan & 1.7 & 1.7 & 1.7 & 1.7 & 1.7 \\
\hline Digestible valine & 6.1 & 6.1 & 6.1 & 6.1 & 6.1 \\
\hline Digestible isoleucine & 5.4 & 5.4 & 5.4 & 5.4 & 5.4 \\
\hline Digestible histidine & 3.7 & 3.7 & 3.7 & 3.7 & 3.7 \\
\hline Arginine & 12.4 & 12.5 & 12.5 & 12.5 & 12.5 \\
\hline
\end{tabular}

${ }^{1}$ Rovimix matrices (Roche) - Composition/kg: vit. A 3,997,500 U.I., vit D3 2,880,000 U.I., vit. E 7,500 U.I., vit K3 1,500 mg, vit. B1 $750 \mathrm{mg}$, vit B2 2,505 mg, vit B6 1,500 mg, vit. B12 7,500 mcg, Acid nicotinic 12,500 mg, Acid pantothenic 4,005 mg, biotin $50 \mathrm{mg}$, Acid folic $500 \mathrm{mg}$, Iron 25,000 mg, Copper 5,000 mg, Zinc 30,000 mg, Manganese 40,000 mg, Selenium $128 \mathrm{mg}$, Iodine $500 \mathrm{mg}$, Cobalt $500 \mathrm{mg}$, Bacitracin Zinc 25,000 mg Antioxidant 15 g, vehicle q.s.p. 1,000 g.

${ }^{2}$ Butylated hydroxytoluene.

Source: Elaboration of the authors.

The experiment was divided into four periods of data collection and egg laying, each corresponding to 28 days. To analyze the performance parameters, the eggs were collected on the last three days of each of the four periods of 28 days.

Feed intake, egg production, egg weight, egg mass and feed conversion per dozen egg masses and performance variables were studied. 
The content analyses of eggs (Haugh unit, albumin index, yolk index and shell thickness) were made with a digital caliper following the methodology described by Snyder (1961). Haugh units were determined later according to the following formula: $\mathrm{UH}=100 \log (\mathrm{H}+7.57-1.7$ $\mathrm{W}$ 0.37), $\mathrm{H}$ being the height of albumin in $\mathrm{mm}$ and $\mathrm{W}=$ egg weight in grams. The specific gravity was obtained by immersing the eggs in plastic buckets containing different salt solutions with densities ranging from 1.0650 to 1.0950 , with intervals of 0.0025 . Shell weight was calculated per unit of surface area (SWSA) using a formula adapted by Rodrigues et al. (1996): SWSA $=[\mathrm{SW} /$ (3.9782 x EW0.7056)] x 100, where SWSA= shell weight per unit surface area; $B W=$ weight of the shell $(\mathrm{G})$; EW $=$ egg weight $(\mathrm{g})$ to determine the quality of the shell around the eggs.

Threonine levels were estimated using the variables of performance and egg quality by polynomial regression analysis through the SAEG program - System for Genetic Analysis and Statistics (version 9.1).

\section{Results and Discussion}

Table 2 contains the results for feed intake and threonine, egg production, feed conversion and weight and egg mass as a function of different levels of threonine.

The consumption variable ration (Table 2) showed no effect $(\mathrm{P}<0.05)$ of different levels of dietary digestible threonine, agreeing with the results obtained by Valerio et al. (2000), who worked with levels ranging from 5.10 to $6.35 \mathrm{~g} / \mathrm{kg}$ of digestible threonine and recommended adding an average of $103.39 \mathrm{~g} / \mathrm{hen} /$ day to the feed intake. Schmidt et al. (2010), working with Lohmann Brown laying hens from 79 to 90 weeks of age, found a quadratic effect of dietary threonine levels on feed intake.

It is noteworthy that the aminoacitic balance of the diet, as well as the composition of the experimental diet, are factors closely related to feed intake (FI) by the hens. Differences in the responses of hens used in the experiments may be relevant.

Table 2. Effect of digestible threonine level on feed intake (FI), consumption of threonine (CT), egg production per hen per day (HD), egg weight (EW), egg mass (EM) and feed conversion $(\mathrm{kg} / \mathrm{kg}$ and $\mathrm{kg} /$ dozen) in laying hens from 75 to 90 weeks of age.

\begin{tabular}{lrrrrrrrrc}
\hline \multirow{2}{*}{ Variable } & \multicolumn{4}{c}{ Level of digestible threonine (g/kg) } & \multicolumn{1}{c}{ CV } & \multicolumn{3}{c}{${\text { Values of } \mathrm{P}^{1}}$} \\
\cline { 2 - 10 } & \multicolumn{1}{c}{4.6} & \multicolumn{1}{c}{5.9} & \multicolumn{1}{c}{5.5} & \multicolumn{1}{c}{5.8} & \multicolumn{1}{c}{$(\%)$} & $\mathrm{L}$ & $\mathrm{Q}$ & $\mathrm{C}$ \\
\hline FI (g/hen/day) & 112.23 & 112.28 & 108.10 & 112.31 & 112.06 & 5.8 & 0.975 & 0.437 & 0.975 \\
$\mathrm{CT}^{2}(\mathrm{mg} /$ hen/day) & 516.26 & 550.17 & 562.12 & 617.71 & 649.45 & 5.7 & 0.000 & 0.430 & 1.000 \\
$\mathrm{HD}(\%)$ & 86.73 & 81.76 & 81.17 & 85.79 & 84.64 & 11.0 & 1.000 & 0.373 & 0.405 \\
EW (g) & 68.26 & 65.33 & 61.88 & 66.41 & 67.00 & 2.1 & 0.859 & 0.128 & 0.674 \\
EM (g/ hen/day) & 59.78 & 53.37 & 53.04 & 55.65 & 56.16 & 9.8 & 0.548 & 0.095 & 0.325 \\
FC (kg/kg) & 1.89 & 2.12 & 2.06 & 2.01 & 2.00 & 2.0 & 0.581 & 0.097 & 0.167 \\
FCDZ (kg/dozen) & 1.87 & 2.00 & 1.91 & 1.85 & 1.92 & 1.0 & 0.836 & 0.802 & 0.147 \\
\hline
\end{tabular}

${ }^{1} \mathrm{~L}, \mathrm{Q}$ and $\mathrm{C}$ : linear, quadratic and cubic order effects.

${ }^{2}$ Linear effect $\mathrm{Y}=-5.597 \mathrm{x}+1125.26\left(\mathrm{R}^{2}=0.97\right)$

Source: Elaboration of the authors.

With the results obtained from FI, it can be inferred that the increased levels of digestible threonine were not sufficient to produce an aminoacitic imbalance that altered the plasma profile of the animals, activating mechanisms regulating the appetite, as described by Harper, 
Benevenga and Wohlhueter (1970).

A linear effect of the digestible threonine level in the diet $(\mathrm{P}>0.05)$ on threonine intake (Table 2) was observed, confirming the results found by Valerio et al. (2000) and Schmidt et al. (2010), who also found a linear increase as threonine was added to the feed of laying hens.

Egg production (Table 2) was not affected $(\mathrm{P}>0.05)$ by the level of digestible threonine. This result differs from Schmidt et al. (2010), who observed that egg production declined the more the threonine level exceeded the daily requirement of the hens. However, it is important to note that the production phases investigated were distinct. Age is also a factor in the productive response of laying.

With respect to egg weight, no effect $(\mathrm{P}<0.05)$ of the level of digestible threonine in the diet was detected, resembling the results of Ishibashi et al. (1998) and Valerius et al. (2000). However, some researchers have reported an increase in egg weight with increased levels of digestible threonine in the diet of laying hens (HUYGHEBAERT; BUTLER, 1991). These discrepancies may be due to the fact that the researchers increased the concentration of total protein in the diet in order to increase the level of threonine.

The egg mass was not affected $(\mathrm{P}>0.05)$ by the level of digestible threonine; thus, the lowest level of the amino acid used $(4.6 \mathrm{~g} / \mathrm{kg})$, met the needs of the hen, accounting for $59.78 \mathrm{~g} / \mathrm{hen} /$ day. This average was greater than that indicated in the Shaver Brown lineage manual (47.05 g/ hen/ day) on egg mass.

From the results shown in Table 2, it can be observed that the level of digestible threonine did not affect $(\mathrm{P}>0.05)$ feed conversion in the poultry (FC and FCDZ), in agreement with Alvarez and Violet (1998), who used levels ranging from 6.20 $\mathrm{g} / \mathrm{kg}$ to $8.7 \mathrm{~g} / \mathrm{kg}$ of dietary digestible threonine on Leghorn hens. These results differ from those of Schmidt et al. (2010), who found a quadratic effect
$(\mathrm{P}>0.01)$ on feed conversion per dozen eggs and pasta.

The divergent results quoted may be related to differences in the genetic structure of the layers, or in their health, nutrition and management conditions (KUL; SEKER, 2004).

The results of this work on feed conversion per kilogram or per dozen eggs showed that diets containing $4.60 \mathrm{~g} / \mathrm{kg}$ of digestible threonine meet the nutritional requirements of laying Shaver Brown pullets after forced molting.

There was no effect $(\mathrm{P}>0.05)$ of the level of digestible dietary threonine on the yolk content and albumin index (Table 3). Therefore, the lowest level of threonine $(0.48 \%)$ was observed in the feed used, supporting the idea that it does not compromise the internal quality of the hens' eggs.

The results for the components of the eggs (percentages of yolk and albumin, shell, shell thickness and shell weight per unit surface area) are shown in Table 3.

The different levels of dietary digestible threonine resulted in a linear effect $(\mathrm{P}>0.05)$ on the variable Haugh unit, which increased to the extent that dietary threonine increased the levels of digestible amino acids in the diet (Table 3), reasonable in view of the participation of this amino acid in egg formation. Matos et al. (2009) found no effect $(\mathrm{P}>0.05)$ of this variable when using different levels of digestible threonine (5.00, 5.50 and $6.00 \mathrm{~g} / \mathrm{kg}$ ); nor did Valerio et al. (2000). This disagrees with the results of this work, possibly because the degree of interference with the internal quality of the eggs produced may be dependent on the strain of laying hens used; in addition, such factors as ambient temperature and the age of the hens may have an influence.

The lack of effect $(\mathrm{P}>0.05)$ for the percentage of yolk corroborates the results of Schmidt et al. (2010), who found no effect of the level of 
digestible threonine working with laying hens 7995 weeks of age, with $25.19 \%$ yolk; whereas, in this experiment, the mean percentage of yolk was $26.15 \%$, showing that the levels of the amino acid threonine used met the needs of the hens as well as for the formation of egg yolk.
For the variable percentage of albumen, there was a quadratic effect $(\mathrm{P}>0.05)$ of increasing the level of digestible threonine in the diet. The greatest impact was seen with $5.20 \mathrm{~g} / \mathrm{kg}$ of digestible threonine, corresponding to the lowest percentage of albumin.

Table 3. Effect of level of digestible threonine on the Haugh (UH), Albumin index (AI), Yolk index (YI), Medium Density (MD), percentages of yolk, albumin and shell (Y, A, S), thickness of bark (TB) and weight per unit bark surface area of laying hens 75-90 weeks of age.

\begin{tabular}{|c|c|c|c|c|c|c|c|c|c|}
\hline \multirow[b]{2}{*}{ Variable } & \multicolumn{5}{|c|}{ Level of digestible threonine (g/kg) } & \multirow{2}{*}{$\begin{array}{l}\text { CV } \\
(\%)\end{array}$} & \multicolumn{3}{|c|}{ Values of $\mathrm{P}^{1}$} \\
\hline & 4.6 & 4.9 & 5.2 & 5.5 & 5.8 & & $\mathrm{~L}$ & Q & $\mathrm{C}$ \\
\hline $\mathrm{UH}^{2}$ & 69.97 & 70.61 & 71.92 & 72.30 & 74.92 & 4.80 & 0.015 & 0.577 & 0.730 \\
\hline AI & 0.60 & 0.56 & 0.60 & 0.51 & 0.59 & 15.07 & 0.634 & 0.449 & 0.367 \\
\hline YI & 0.39 & 0.38 & 0.39 & 0.39 & 0.38 & 3.29 & 0.524 & 0.625 & 0.253 \\
\hline $\mathrm{MD}^{3}$ & 1.082 & 1.086 & 1.088 & 1.084 & 1.084 & 0.37 & 0.727 & 0.042 & 0.180 \\
\hline $\mathrm{Y}(\%)$ & 25.91 & 26.55 & 26.02 & 26.31 & 25.81 & 2.92 & 0.568 & 0.180 & 0.773 \\
\hline $\mathrm{A}^{4}(\%)$ & 65.00 & 63.82 & 64.40 & 64.21 & 64.80 & 1.27 & 1.000 & 0.035 & 0.358 \\
\hline $\mathrm{S}^{5}(\%)$ & 9.07 & 9.70 & 9.56 & 9.46 & 9.38 & 3.70 & 0.410 & 0.016 & 0.101 \\
\hline TB (mm) & 0.47 & 0.49 & 0.48 & 0.46 & 0.47 & 3.82 & 0.127 & 0.557 & 0.030 \\
\hline SWSA $\left(\mathrm{mg} / \mathrm{cm}^{2}\right)$ & 7.90 & 8.34 & 8.23 & 8.13 & 8.10 & 3.92 & 0.654 & 0.069 & 0.140 \\
\hline
\end{tabular}

${ }^{1} \mathrm{~L}, \mathrm{Q}$ e C: Effects linear, quadratic and cubic order

${ }^{2}$ Linear effect; $\mathrm{Y}=51.8634+38.6312 \mathrm{x}\left(\mathrm{R}^{2}=0.92\right)$

${ }^{3}$ Quadratic effect; $\mathrm{Y}=0.800490-1.09747 \mathrm{x}+1.05026 \mathrm{x} 2 ;(\mathrm{R} 2=0.84)$

${ }^{4}$ Quadratic effect; $Y=219.84 \mathrm{x}^{2}-228.67 \mathrm{x}+123.51\left(\mathrm{R}^{2}=0.6215\right)$

${ }^{5}$ Quadratic effect; $\mathrm{Y}=-20.8078+115.833 \mathrm{x}-110.158 \mathrm{x}^{2}\left(\mathrm{R}^{2}=0.14\right)$

Source: Elaboration of the authors.

The Haugh unit was influenced by the level of digestible threonine in the diet. This variable linear effect was observed increasing with increasing levels of amino acids.

The shell thickness and shell weight per unit surface area (Table 3) were not affected $(\mathrm{P}>0.05)$ by dietary digestible threonine, indicating that there was no deficiency of amino acids to meet the needs of the hens. Similar results were found by Schmidt et al. (2010) and Cupertino et al. (2009).

The percentage of bark showed a quadratic effect $(\mathrm{P}>0.05)$ in relation to the level of digestible threonine in the diet. The estimated threonine requirement for the best average percentage of bark was $5.25 \mathrm{~g} / \mathrm{kg}$ of digestible threonine, which is equivalent to $0.562 \mathrm{~g}$ of threonine/hen/day.

The average density (Table 3 ) was influenced $(\mathrm{P}>0.05)$ by the level of digestible threonine in the diet. The suggested level of $5.22 \mathrm{~g} / \mathrm{kg}$ of digestible threonine, which corresponds to $0.651 \mathrm{~g}$ threonine/ hen/day, was obtained using the quadratic equation $\mathrm{Y}=0.800490-1.09747 \mathrm{x}+1.05026 \mathrm{x} 2 ;(\mathrm{R} 2=0.84)$. This result is less than the value quoted by Teixeira, Vilar da Silva and Silva (2005), which assessed levels ranging from 3.70 to $7.90 \mathrm{~g} / \mathrm{kg}$ of digestible threonine in the diet of laying hens, and found improvements in density, suggesting therefore 5.30 $\mathrm{g} / \mathrm{kg}$ of digestible threonine.

These differences are perhaps due to temperature, management, nutritional factors and the age of the 
hens interfering with the threonine requirement in terms of specific gravity as well as to solutions concentrating by evaporation when losses occur, and also to cracks peeling or movement in water (Freitas et al. 2004).

\section{Conclusions}

To provide the best performance and quality of eggs, hens need $5.25 \mathrm{~g} / \mathrm{kg}$ of digestible threonine, which corresponds to consuming $0.562 \mathrm{~g}$ of digestible threonine/hen/day.

\section{References}

ALETOR, V. A.; HAMID, I. I.; NIESS, E. Low-protein amino acid-supplemented diets in broiler chickens: Effect on performance, carcass characteristics, whole body composition and efficiencies nutrient utilization. Journal Science Food Agriculture, Chichester, v. 80, n. 5, p. 547-554, 2000.

ALVAREZ, E.; VIOLETA, A. Efecto del nivel de L-treonina en dietas para gallinas de postura comercial durante el período de la semana 33 a la 41 de edad. 1998. Monografia (Graduação em Zootecnia) - Univesidad de San Carlos de Guatemala, Guatelama.

CUPERTINO, E. S.; GOMES, P. C.; ROSTAGNO, H. S.; DONZELE, J, L.; SCHMIDT, M.; CARVALHO MELO, H. H. Exigência nutricional de metionina+cistina para galinhas poedeiras de 54 a 70 semanas de idade. Revista Brasileira de Zootecnia, Viçosa, v. 38, n. 7, p. 12381246, 2009.

FARIA, D. E.; JUNQUEIRA, O. M.; SOUZA, P. A.; TITTO, E. A. L. Desempenho, temperatura corporal e qualidade de ovos de poedeiras alimentadas com vitamina $\mathrm{D}$ e C em três ambientes. Revista Brasileira de Ciência Avícola, Campinas, v. 3, n. 1, p. 49-56, 2001.

FREITAS, E. R.; SAKOMURA, N. K.; GONZALEZ, M. M.; BARBOSA, N. A. A. Comparação de métodos de determinação da gravidade específica da gravidade específica de ovos de poedeiras comerciais. Pesquisa Agropecuária Brasileira, Brasília, v. 39, n. 5, p. 509-512, 2004.

HARPER, A. E.; BENEVENGA, N. J.; WOHLHUETER, R. M. Effects of ingestion of disproportionate amounts of amino acids. Physiological Reviews, Bethesda, v. 50, n. 3, p. 428-558, 1970.
HUYGHEBAERT, G.; BUTLER, E. A. Optimun threonine requirements of laying hens. British Poultry Science, Merelbeke, v. 32, n. 3, p. 575-582, 1991.

ISHIBASHI, T.; OGAWA, Y.; ITOH, T.; FUJIMURA, S.; KOIDE, K.; WATANABE, R. Threonine requeriment of laying hens. Poultry Science, Mississipi, v. 77, n. 7, p. 998-1002, 1998.

KUL, S.; SEKER, I. Phenotypic correlations between some external and internal egg quality traits in the Japanese quail. International Journal of Poultry Science, Faisalabad, v. 3, n. 6, p. 400-405, 2004.

LEESON, S.; SUMMERS, J. D. Nutrition of the chicken. Ontario: University of Guelf, 2001. 482 p.

MATOS, M.; LEANDRO, M. N.; CARVALHO, F. B.; STRINGHINI, J. H.; CAFÉ, M. B.; LOPES, K. L. Níveis de lisina e treonina digestíveis na ração de poedeiras comerciais sobre a qualidade de ovos. Animal Sciences, Maringá, v. 31, n. 1, p. 25-29, 2009.

MEDINA, G. J. R. Avanços na nutrição da poedeira moderna. Campinas: CNBA, 2003. 21 p.

RODRIGUES, P. B.; BERTECHINI, A. G.; OLIVEIRA, B. C.; TEIXEIRA, A. S.; OLIVEIRA, A. I. G. O. Fatores nutricionais que influenciam a qualidade do ovo no segundo ciclo de produção. I. Níveis de aminoácidos sulfurosos totais. Revista Brasileira de Zootecnia, Viçosa, v. 25, n. 2, p. 248-260, 1996.

ROSTAGNO, H. S.; ALBINO, L. F. T.; DONZELE, J. L.; GOMES, P. C.; OLIVEIRA, R. F.; LOPES, D. C.; FERREIRA, A. S.; BARRETO, S. L. T.; EUCLIDES, R. F. Tabelas brasileiras para aves e suínos: composição de alimentos e exigências nutricionais. Viçosa, MG: Editora UFV, 2000. $141 \mathrm{p}$.

ROSTAGNO, H. S.; ALBINO, L. F. T.; PAEZ, L. E. Uso da proteína ideal para formular dietas de frangos de corte. In: SEMINÁRIO TÉCNICO AJINOMOTO BIOLATINA, 1., 2006, São Paulo. Anais... São Paulo: ABRAVES, 2005. p. 1-17.

SCHMIDT, M.; ROSTAGNO, H. S.; NUNES, R. V.; PUPA, J. M. R.; GOMES, P. C. Níveis nutricionais de lisina, de metionina + cistina e de treonina digestíveis para galinhas poedeiras no $2^{\circ}$ ciclo de produção. Revista Brasileira de Zootecnia, Viçosa, v. 39, n. 5, p. 10991104, 2010.

SNYDER, E. S. Eggs, the production, the identification and retention of quality in eggs. Guelph: Ontario Agricultural College, $1961.90 \mathrm{p}$. 
TEIXEIRA, E. N. M.; VILAR DA SILVA, J. H.; SILVA, E. L. Exigência de treonina digestível para poedeiras leves e semipesada. In: CONFERÊNCIA APINCO DE CIÊNCIA E TECNOLOGIA AVÍCOLAS, 2005, Santos. Anais... Santos, 2005. p. 131.

UMIGI, R. T.; GOMES, P. C.; CECON, P. R.; ROSTAGNO, H. S.; D' AGOSTINI, P. Níveis de treonina em dietas para codorna japonesa em postura. Revista Brasileira de Zootecnia, Viçosa, v. 36, n. 6, p. 1868-1874, 2007.
VALÉRIO, S. R.; SOARES, P. R.; ROSTAGNO, H. S.; ALMEIDA E SILVA, M.; ALBINO, L. F. T.; LANA, G. R. Q.; GOULART, C. C.; KILL, J. L. Determinação da exigência nutricional de treonina para poedeiras leves e semipesadas. Revista Brasileira de Zootecnia, Viçosa, v. 29, n. 2, p. 518-524, 2000. 